\title{
Studies on Hydroperoxide-Dependent Substrate Hydroxylation by Purified Liver Microsomal Cytochrome P-450
}

\author{
GERALD D. NORDBLOM, RONALD E. WHITE, ${ }^{2}$ AND MINOR J. COON \\ Department of Biological Chemistry, Medical School, The University of Michigan, \\ Ann Arbor, Michigan 48109
}

Received January 30, 1976

\begin{abstract}
Highly purified liver microsomal cytochrome $P-450$ catalyzes the hydroperoxide-dependent hydroxylation of a variety of substrates in the absence of NADPH, NADPHcytochrome $P-450$ reductase, and molecular oxygen. The addition of phosphatidylcholine is necessary for maximal activity. The absence of flavoproteins and cytochrome $b_{5}$ from the cytochrome $P-450$ preparations rules out the involvement of other known microsomal electron carriers. The ferrous form of cytochrome $P-450$ is not involved in peroxidedependent hydroxylation reactions, as indicated by the lack of inhibition by carbon monoxide. With cumene hydroperoxide present, a variety of substrates is attacked, including $N$-methylaniline, $N, N$-dimethylaniline, cyclohexane, benzphetamine, and aminopyrine. With benzphetamine as the substrate, cumene hydroperoxide may be replaced by other peroxides, including hydrogen peroxide, or by peracids or sodium chlorite. A study of the stoichiometry indicated that equimolar amounts of $N$-methylaniline, formaldehyde, and cumyl alcohol ( $\alpha, \alpha$-dimethylbenzyl alcohol) are formed in the reaction of $N, N$-dimethylaniline with cumene hydroperoxide. Since $\mathrm{H}_{2}{ }^{18} \mathrm{O}$ is incorporated only slightly into cyclohexanol in the reaction of cyclohexane with cumene hydroperoxide, it appears that the oxygen atom in cyclohexanol is derived primarily from the peroxide. The data obtained are in accord with a peroxidase-like mechanism for the action of cytochrome $P-450$.
\end{abstract}

The mixed function oxidase of liver microsomal membranes is capable of hydroxylating or otherwise metabolizing fatty acids and steroids as well as a variety of foreign compounds, including drugs, insecticides, alkanes, anesthetics, and carcinogens. This enzyme system was resolved into three components, $P-450_{\mathrm{LM}},{ }^{3} \mathrm{NADPH}-$ cytochrome $P-450$ reductase, and phosphatidylcholine (3-6), and more recently our

\footnotetext{
1 This research was supported by Grant BMS7101195 from the National Science Foundation and Grant AM-10339 from the United States Public Health Service. Preliminary reports of part of this investigation have been presented $(1,2)$.

2 Postdoctoral Fellow, United States Public Health Service.

${ }^{3}$ Abbreviations used: $P-450_{\mathrm{LM}}$, liver microsomal cytochrome $P-450 ; P-450_{\mathrm{LM}_{2}}$, phenobarbital-inducible form of $P-450_{\mathrm{LM}}$; dilauroyl-GPC, dilauroylglyceryl-3-phosphorylcholine; SDS, sodium dodecyl sulfate.
}

laboratory has described the purification and characterization of multiple forms of $P-450_{L M}$ from rabbit liver (7-9).

The hydroxylation reaction mechanism is only partly understood. Under anaerobic conditions two electrons are transferred from NADPH to the $P-450_{\mathrm{LM}}$-substrate complex via the reductase, one to the iron atom and the other to an unidentified acceptor $(10,11)$. Molecular oxygen is bound to the ferrocytochrome to form a ternary complex, as shown by Estabrook et al. (12) with liver microsomal suspensions and by Gunsalus et al. (13) and by Ishimura et al. (14) with bacterial cytochrome $P-450$. We have recently confirmed the formation of the oxyferro complex in steady-state experiments with purified $P-450_{\mathrm{LM}}{ }^{4}$ Electron transfer to the oxygen is believed to

\footnotetext{
${ }^{4}$ Guengerich, F. P., Ballou, D. P., and Coon, M. J., unpublished results.
} 
occur with production of an "activated oxygen" capable of attacking the substrate; the possible involvement of superoxide in this process has been reported (15). Evidence has been presented for hydroperoxides as intermediates in the biological hydroxylation of tetralin (16), fluorene (17), and cholesterol (18). More recently, the ability of liver microsomal suspensions to utilize organic hydroperoxides for the hydroxylation of various substrates and the possible role of cytochrome $P$-450 in these reactions have been reported by several laboratories (19-24).

In the present paper, highly purified $P$ $450_{\mathrm{LM}}$ is shown to catalyze the peroxidedependent hydroxylation of various substrates in the absence of NADPH and the reductase. The cytochrome preparations used appeared to be homogeneous by gel electrophoresis and were known to be free of other microsomal electron carriers such as flavoproteins and cytochrome $b_{5}$.

\section{EXPERIMENTAL PROCEDURES}

Highly purified $P-450_{\mathrm{L} M}$ was prepared from phenobarbital-induced rabbits as described previously $(7,8)$. This form of the cytochrome, which is designated by its relative electrophoretic inubility as $P$. $450_{\mathrm{LM}_{2}}(9)$, migrates as a single polypeptide band of molecular weight 50,000 when analyzed by sodium dodecyl sulfate-polyacrylamide-gel electrophoresis. Apparently due to the variable loss of heme during purification, the cytochrome $P-450$ content of the preparations varied from 10.9 to $16.9 \mathrm{nmol} / \mathrm{mg}$ of protein. Preparations with a specific content of 16.9 were used in all of the experiments described in the present paper except in the initial studies on substrate and oxidant specificity and general requirements of the system.

$\mathrm{D}-\left[N-\right.$ methyl $\left.-{ }^{14} \mathrm{C}\right]$ benzphetamine was generously provided by Dr. A. Y. H. Lu, Hoffman-La Roche Inc. and $\left[N-\right.$ methyl- $\left.{ }^{14} \mathrm{C}\right]$ aminopyrine by $\mathrm{Dr} . \mathrm{D}$. W. Nebert, National Institutes of Health. $\left[\mathrm{U}-{ }^{14} \mathrm{C}\right]$ cyclohexane was obtained from Amersham/Searle; dilauroyl-GPC from Serdary Research Laboratories, London, Ontario; horseradish peroxidase (type VI), hemin chloride (type III), and bovine liver catalase (twice crystallized) from Sigma; $N, O$-bis(trimethylsilyl acetamide from Regis; cumene hydroperoxide and $p$-menthyl hydroperoxide from ICN-K \& K Laboratories; $t$-butyl hydroperoxide, $m$-chloroperbenzoic acid, and $p$-nitroperbenzoic acid from Aldrich; and ethyl hydroperoxide from Gallard-Schlesinger. The cumene hydroperoxide was routinely purified by extraction with alkali (25); the resulting material was 95 to $98 \%$ pure. Ethyl isocyanide was prepared by the method of Schuster et al. (26), while benzyl ether and methyl cumyl ether (methyl $\alpha, \alpha$-dimethylbenzyl ether) were prepared by treatment of the corresponding alkyl chlorides with methanol (27). Cumyl chloride was prepared by the method of Brown et al. (28), $n$-Hexylhydroperoxide was made by the reaction of $n$-hexyl tosylate with alkaline hydrogen peroxide according to a general published procedure (29). The concentration of all hydroperoxides was determined iodometrically $(30)$. Water containing $95 \%{ }^{18} \mathrm{O}$ was obtained from Koch Isotopes.

Assay of substrate hydroxylation and demethylation. The components of the reaction mixtures were added in the following order and, unless stated otherwise, were at the final concentrations indicated: $P-450_{\mathrm{LM}}(1.0 \mu \mathrm{M})$, dilauroyl-GPC $(0.06 \mathrm{mM}$ when hydrogen peroxide was present or $0.15 \mathrm{~mm}$ when cumene hydroperoxide was present), potassium phosphate buffer, $\mathrm{pH} 7.4(0.1 \mathrm{~m})$, substrate, and either hydrogen peroxide ( $50 \mathrm{~mm}$ ) or cumene hydroperoxide $(3.3 \mathrm{~mm})$ to initiate the reaction. The phospholipid was added in the form of a sonicated micellar suspension and was at the minimal concentration required for maximal reaction rates, as shown in experiments not presented here. The reaction mixtures had a final volume of $1.0 \mathrm{ml}$ when radioactive substrates were used ( $10 \mathrm{~mm}$ cyclohexane in $0.01 \mathrm{ml}$ of acetone, $1.0 \mathrm{~mm}$ benzphetamine, or $10 \mathrm{~mm}$ aminopyrine) or $1.5 \mathrm{ml}$ when other substrates were used and were incubated at $30^{\circ} \mathrm{C}$. The $N$-demethylation of radioactive benzphetamine $\left(1.2 \times 10^{5} \mathrm{cpm} / \mu \mathrm{mol}\right)$ and aminopyrine $\left(1.6 \times 10^{5} \mathrm{cpm} / \mu \mathrm{mol}\right)$ was determined by the method of Poland and Nebert (31) and the hydroxylation of radioactive cyclohexane $(1.8 \times$ $10^{5} \mathrm{cpm} / \mu \mathrm{mol}$ ) by isolation of the resulting cyclohexanol according to the chromatographic procedure of Gholson et al. (32). In initial experiments (Table I) the $N$ - or $O$-demethylation of other substrates was measured by formaldehyde determination by the method of Nash (33) as modified by Cochin and Axelrod (34). In subsequent experiments, color development was carried out for $35 \mathrm{~min}$ at $25^{\circ} \mathrm{C}$; under these modified conditions slightly greater accuracy was obtained because the formaldehyde was then completely stable in the presence of the hydroperoxide. All experiments were carried out in duplicate or triplicate and included controls in which $P-450_{\mathrm{LM}}$ was omitted. The data presented are average values.

\section{RESULTS}

Hydroxylation of substrates by $P-450_{\mathrm{LM}}$ in presence of cumene hydroperoxide. In initial experiments a series of possible substrates was tested for activity when cumene hydroperoxide was substituted for NADPH and NADPH-cytochrome $P-450$ 
reductase in the usual reconstituted enzyme system (35). The results shown in Table I indicate that cyclohexane was converted to cyclohexanol and that a variety of $\mathrm{N}$ - and $O$-methyl compounds, including benzphetamine and aminopyrine, underwent demethylation to produce formaldehyde. Since subsequent experiments indicated that the conditons may not have been optimal with all of the substrates, the activities shown should be taken as approximate values. The purified $P-450_{\mathrm{LM}}$ used contained apoenzyme but was apparently homogeneous as judged by SDSpolyacrylamide-gel electrophoresis and was known to be free of other microsomal electron carriers such as flavoproteins and cytochrome $b_{5}$.

Benzphetamine demethylation in the presence of cumene hydroperoxide and related compounds. A variety of other potential oxygenating agents was substituted for cumene hydroperoxide in the $P-450_{\mathrm{LM}^{-}}$

TABLE I

Hydroxylation of Various Substrates by Cytochrome $P$-450 In Presence of Cumene HYDROPEROXIDE $^{a}$

\begin{tabular}{lcc}
\hline Substrate tested & $\begin{array}{c}\text { Substrate } \\
\text { concentra- } \\
\text { tion } \\
(\mathrm{mM})\end{array}$ & $\begin{array}{c}\text { Activity } \\
\text { (nmol } \\
\text { product } \\
\text { formed/ } \\
\text { nmol cyto- } \\
\text { chrome } P \text { - } \\
450)\end{array}$ \\
\hline$N, N$-dimethylaniline & 5.0 & 290 \\
$N$-methylaniline & 5.0 & 259 \\
Cyclohexane & 10.0 & 198 \\
$N$-methylbenzylamine & 6.7 & 50 \\
Methyl cumyl ether & 6.7 & 42 \\
Benzphetamine & 1.0 & 30 \\
$N$-methyl- $n$-butylamine & 6.7 & 29 \\
Aminopyrine & 10.0 & 12 \\
Methyl octanoate & 6.7 & 8 \\
Methyl benzyl ether & 20.0 & $4^{b}$ \\
\hline
\end{tabular}

${ }^{a}$ Various substrates were tested at the concentrations indicated in reaction mixtures containing $P-450_{\mathrm{LM}}$, cumene hydroperoxide, and phosphatidylcholine. The concentrations of the other components and the order of addition were as described in the section on experimental procedures. The reaction mixtures were incubated for $15 \mathrm{~min}$ at $30^{\circ} \mathrm{C}$. A control experiment established that cumene hydroperoxide does not yield a significant amount of formaldehyde in the absence of an added substrate.

${ }^{b}$ This low value is of doubtful significance.

\section{TABLE II}

Benzphetamine Demetirylation Catalyzed by Cytochrome $P-450$ in the Presence of Various Oxygenating Agents ${ }^{a}$

\begin{tabular}{lc}
\hline Oxygenating agent & $\begin{array}{c}\text { Activity } \\
\text { (nmol product } \\
\text { formed/nmol cy- } \\
\text { tochrome } P \text {-450) }\end{array}$ \\
\hline Cumene hydroperoxide & 30 \\
$p$-Nitroperbenzoic acid & 15 \\
$m$-Chloroperbenzoic acid & 12 \\
$p$-Menthyl hydroperoxide & 10 \\
Hydrogen peroxide & 8 \\
Sodium chlorite & 6 \\
t-Butyl hydroperoxide & 4 \\
$n$-Hexyl hydroperoxide & 2 \\
Ethyl hydroperoxide & 2
\end{tabular}

${ }^{a}$ The conditions were as in Table I, except that various oxygenating agents $(3.3 \mathrm{~mm})$ were used and radioactive benzphetamine $(1.0 \mathrm{~mm})$ served as the substrate. The dilauroyl-GPC concentration was $0.15 \mathrm{~mm}$ in all of the experiments.

catalyzed demethylation of [N-methyl${ }^{14} \mathrm{Clbenzphetamine}$ with the results shown in Table II. Cumene hydroperoxide was the most effective under the conditons used, which were not necessarily optimal, but activity was also shown by other peroxides as well as by peracids and sodium chlorite. Due to the high sensitivity of the radioactivity assay, all of the activities shown are significant.

Kinetics of the reaction and evidence for destruction of $P-450_{\mathrm{LM}}$ by peroxides. $P$ $450_{\mathrm{LM}}$ heme was degraded with time, as determined by measurements of the Soret band of the oxidized protein at $417 \mathrm{~nm}$ (Fig. 1). Cumene hydroperoxide was particularly destructive alone or in the presence of benzphetamine but not with $N$ methylaniline present. In experiments not shown the $P-450_{\mathrm{LM}}$ loss was confirmed by measuring the pyridine hemochromogen and the $\mathrm{CO}$ difference spectrum of the reduced protein at $450 \mathrm{~nm}$ (36). However, by limiting the concentration of the peroxides the reactions could be made linear with certain substrates for a brief time. As shown in Fig. 2, $\mathrm{N}$-methylaniline demethylation in the presence of $1.0 \mathrm{~mm}$ cumene hydroperoxide was linear for at least 2.5 min and benzphetamine demethylation in the presence of $50 \mathrm{~mm}$ hydrogen peroxide for $5 \mathrm{~min}$. In subsequent studies of these $P$. 


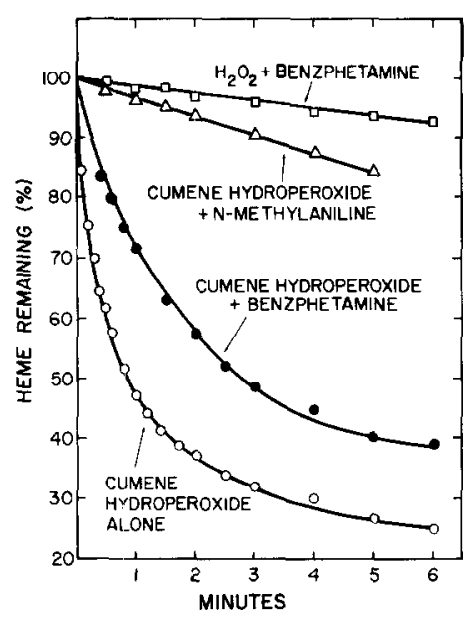

FIG. 1. Heme destruction as a function of time. The reaction mixtures contained $0.5 \mu \mathrm{M} P-450_{\mathrm{LM}}$ and the peroxides and substrates indicated; the usual conditions were employed except that cumene hydroperoxide was $1.5 \mathrm{mM}$ and $N$-methylaniline 5.0 mM.

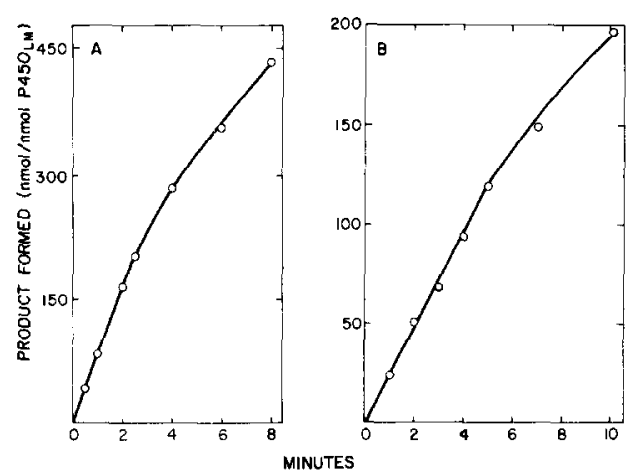

FIG. 2. Substrate demethylation by cytochrome $P .450$ as a function of time in the presence of a peroxide. In Expt A cumene hydroperoxide (1.0 mM) was used with $\mathrm{N}$-methylaniline $(6.7 \mathrm{~mm})$ as the substrate, and in Expt $B$ hydrogen peroxide $(50 \mathrm{~mm})$ was used with benzphetamine (1.0 mM) as the substrate. The individual reaction mixtures were incubated for the time intervals indicated.

$450_{\mathrm{LM}}$-catalyzed reactions, measurements were made within these linear ranges.

Required components and effects of inhibitors. As indicated in Table III, benzphetamine demethylation shows a complete dependence on $P-450_{\mathrm{LM}}$, which cannot be replaced by boiled enzyme, P- $420_{\mathrm{LM}}$, heme, or ferric ions at the same concentration. The reaction is also completely dependent on the presence of hydrogen per- oxide and requires phosphatidylcholine for full activity. Unlike the usual reconstituted microsomal system which requires molecular oxygen when NADPH serves as the electron donor in the presence of the reductase, the peroxide-dependent demethylation is unaffected when $\mathrm{O}_{2}$ is replaced by $\mathrm{N}_{2}$ or $\mathrm{CO}$ under highly anaerobic

TABLE III

Requirements for SUbSTrate Hydroxylation

\begin{tabular}{|c|c|c|}
\hline \multirow[t]{2}{*}{ System $^{a}$} & \multicolumn{2}{|c|}{$\begin{array}{l}\text { Rate of formaldehyde } \\
\text { formation (nmol(nmol } \\
\left.P-450)^{-1} \min ^{-1}\right)\end{array}$} \\
\hline & $\begin{array}{l}\text { Benzphe- } \\
\text { tamine de- } \\
\text { methyla- } \\
\text { tion with } \\
\text { hydrogen } \\
\text { peroxide }\end{array}$ & $\begin{array}{c}N \text {-methyl- } \\
\text { aniline de- } \\
\text { methyla- } \\
\text { tion with } \\
\text { cumene } \\
\text { hydroper- } \\
\text { oxide }\end{array}$ \\
\hline Complete & 27 & 84 \\
\hline $\begin{array}{l}\text { Complete, but } P-450_{\mathrm{LM}} \\
\text { heat inactivated }^{b}\end{array}$ & 2 & \\
\hline No $P-450_{\mathrm{LM}}$ & 0 & 0 \\
\hline $\begin{array}{l}\text { No } P-450_{\mathrm{LM}} ; P-420_{\mathrm{LM}}(1.0 \\
\mu \mathrm{M}) \text { added }\end{array}$ & 0 & \\
\hline $\begin{array}{l}\text { No } P-450_{L M} ; \text { hemin chlo- } \\
\text { ride }(1.0 \mu \mathrm{M}) \text { added }\end{array}$ & 0 & \\
\hline $\begin{array}{l}\text { No } P-450_{\mathrm{LM}} ; \mathrm{FeCl}_{3}(1.0 \\
\mu \mathrm{M}) \text { added }\end{array}$ & 0 & \\
\hline No peroxide & 0 & 0 \\
\hline No dilauroyl-GPC & 14 & 24 \\
\hline No $\mathrm{O}_{2}\left(\mathrm{~N}_{2} \text { present }\right)^{\prime}$ & 27 & \\
\hline $\mathrm{No}_{2}$ (CO present) $)^{r}$ & 28 & \\
\hline $\begin{array}{l}\text { Complete }+ \text { cyanide }(5.0 \\
\text { mM })\end{array}$ & 12 & 10 \\
\hline $\begin{array}{l}\text { Complete }+ \text { ethyl iso- } \\
\text { cyanide }(5.0 \mathrm{~mm})\end{array}$ & 5 & 25 \\
\hline $\begin{array}{l}\text { Complete + SKF 525-A } \\
\quad(2.0 \mathrm{mM})\end{array}$ & 2 & \\
\hline
\end{tabular}

${ }^{a}$ The complete systems were as in Fig. 1, except that the incubation times were in the linear range (1.5 min with hydrogen peroxide and $2 \mathrm{~min}$ with cumene hydroperoxide). To prepare $P-420_{\mathrm{LM}}, P-450_{\mathrm{LM}}$ was dialyzed overnight at $4^{\circ} \mathrm{C}$ against 200 volumes of $0.05 \mathrm{M}$ phosphate buffer, $\mathrm{pH} 7.4$, to remove the glycerol; urea was then added to a final concentration of $6.0 \mathrm{M}$, and the solution was stirred at room temperature for $20 \mathrm{~min}$. The urea was removed by dialysis for $3 \mathrm{~h}$ against 200 volumes of phosphate buffer at room temperature and then overnight after a change of buffer. The incubation time in each experiment was $1.5 \mathrm{~min}$.

${ }^{b}$ The enzyme was boiled for $10 \mathrm{~min}$ at $100^{\circ} \mathrm{C}$.

c The gases were freed of $\mathrm{O}_{2}$ by passage through a train containing BASF catalyst (10). 
conditions. The failure of carbon monoxide to inhibit the reaction suggests that the ferrous form of $P-450_{\mathrm{LM}}$ is not involved. On the other hand, cyanide and ethyl isocyanide, which are capable of serving as ligands to the iron atom in the ferric form of $P-450_{\mathrm{LM}}(37,38)$, are effective inhibitors. SKF 525-A, a known inhibitor of many microsomal hydroxylation reactions, is also inhibitory in the hydrogen peroxidedependent demethylation of benzphetamine. Similar but less extensive studies were carried out on $N$-methylaniline demethylation, which is also completely dependent on the presence of the peroxide used (cumene hydroperoxide) and $P-450_{\mathrm{LM}}$ and requires phospholipid for full activity.

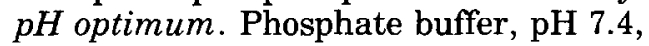
was used in the various experiments because this is about the $\mathrm{pH}$ optimum in the complete reconstituted system (5). The $\mathrm{pH}$ optimum was determined with two substrates, as shown in Fig. 3. The results show that with $N$-methylaniline the cumene hydroperoxide-dependent reaction has a broad $\mathrm{pH}$ optimum centered at $\mathrm{pH}$ 7.5 , whereas the hydrogen peroxide-dependent reaction increases with increasing $\mathrm{pH}$ through the range studied. The reason for this difference is not known.

Other hemeproteins. In view of the finding that $P-450_{\mathrm{LM}}$ catalyzes hydroxylation reactions in the presence of peroxides, the ability of horseradish peroxidase and catalase to catalyze benzphetamine demethylation in the presence of oxygenating agents was also examined (Table IV). Under the conditions used, catalase appeared to be slightly active with cumene hydroperoxide, and horseradish peroxidase was highly active but only with sodium chlorite. It should be noted that Gillette et al. (39) and Kadlubar et al. (19) have observed $N$-dealkyation by hemeproteins under different conditions from those employed in the present study.

Effect of peroxide and substrate concentrations on kinetics. The results obtained when the concentration of hydrogen peroxide or cumene hydroperoxide was varied in the usual system containing $P-450_{\mathrm{LM}}$, dilauroyl-GPC, and substrate (benzphetamine with hydrogen peroxide or $N$-methyl-

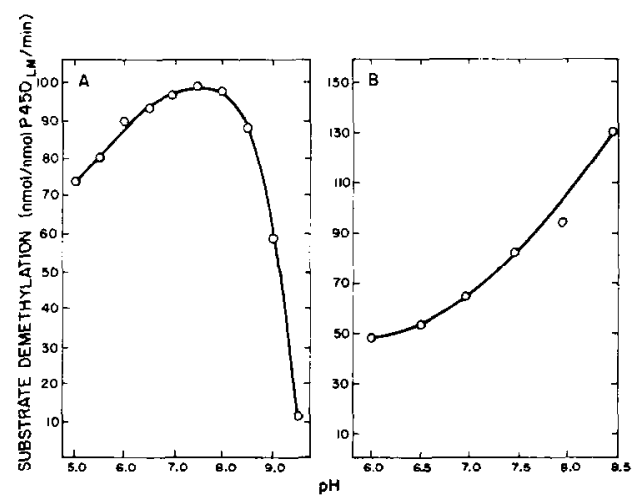

FIG. 3. Effect of $\mathrm{pH}$ on $N$-methylaniline demethylation in the presence of cumene hydroperoxide (Expt A) or aminopyrine demethylation in the presence of hydrogen peroxide (Expt B). Aminopyrine was used rather than benzphetamine because of the insolubility of the latter compound above $\mathrm{pH} 7.4$. The usual conditions were employed but with phosphate buffers of varying $\mathrm{pH}$. The incubation time was $1.5 \mathrm{~min}$ with hydrogen peroxide and $2 \mathrm{~min}$ with cumene hydroperoxide.

TABLE IV

Benzphetamine Demethylation Catalyzed by Horseradish Peroxidase and Catalase in

Presence of Various Oxygenating Agents ${ }^{a}$

\begin{tabular}{lcc}
\hline \multicolumn{1}{c}{ Oxygenating agent } & $\begin{array}{c}\text { Activity (nmol prod- } \\
\text { uct formed/nmol } \\
\text { hemeprotein) }\end{array}$ \\
\cline { 2 - 3 } & $\begin{array}{c}\text { Horserad- } \\
\text { ish peroxi- } \\
\text { dase }\end{array}$ & $\begin{array}{c}\text { Cata- } \\
\text { lase }\end{array}$ \\
\hline Cumene hydroperoxide & 1 & 5 \\
Hydrogen peroxide & 0 & 0 \\
Sodium chlorite & 107 & 0 \\
\hline
\end{tabular}

a The usual components were present, including $0.15 \mathrm{mM}$ dilauroyl-GPC, but with $1.0 \mu \mathrm{M}$ peroxidase or catalase in place of $P-450_{\mathrm{LM}}$. The incubation time was $15 \mathrm{~min}$. The concentration of the oxygenating agents was $3.3 \mathrm{~mm}$.

aniline with cumene hydroperoxide) are given in the double-reciprocal plots in Fig. 4. The apparent $K_{m}$ of $\mathrm{H}_{2} \mathrm{O}_{2}$ is $250 \mathrm{mM}$, and the estimated $V_{\max }$ of the demethylation of benzphetamine is $140 \mathrm{nmol}$ ( $\mathrm{nmol}$ of $P$ $\left.450_{\mathrm{LM}}\right)^{-1} \mathrm{~min}^{-1}$. The apparent $K_{m}$ of cumene hydroperoxide is $0.68 \mathrm{~mm}$, and the estimated $V_{\max }$ of the cumene hydroperoxide-supported demethylation of $N$-methylaniline is 147. The concentrations of benzphetamine and $N$-methylaniline were 

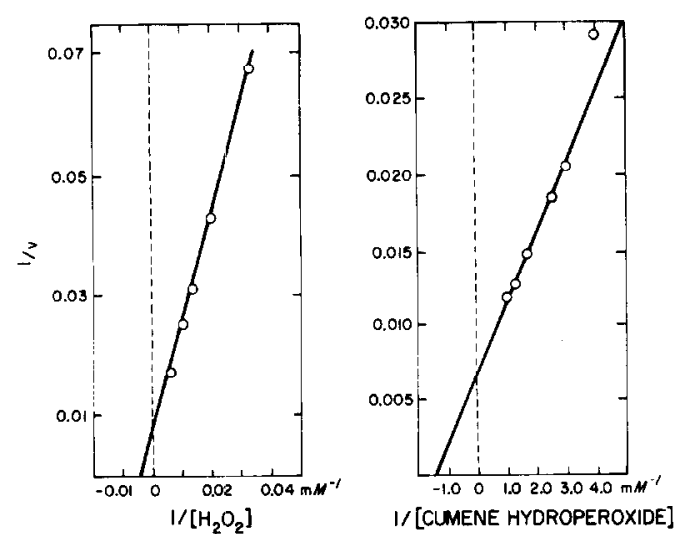

FIG. 4. $K_{m}$ values of hydrogen peroxide and cumene hydroperoxide determined by LineweaverBurk plots. The usual conditions were used with $N$ methylaniline $(6.7 \mathrm{~mm})$ or benzphetamine $(1.0 \mathrm{~mm})$ as substrate. The incubation times were 1 or $2 \mathrm{~min}$, respectively. Velocity is expressed as nanomoles of formaldehyde liberated per nanomole of $P-450_{\mathrm{LM}}$ per minute.

then varied at several peroxide concentrations with the results shown in Fig. 5. The $K_{m}$ of benzphetamine in the $\mathrm{H}_{2} \mathrm{O}_{2}$-supported reactions was $0.18 \mathrm{~mm}$ and was independent of the $\mathrm{H}_{2} \mathrm{O}_{2}$ concentration over the 15 -fold range tested; a similar value has been obtained in the complete reconstituted system containing $\mathrm{P}-45 \mathrm{LM}_{\mathrm{LM}_{2}}$, reductase, NADPH, and phospholipids. ${ }^{5}$ In contrast, the apparent $K_{m}$ of $N$-methylaniline was decreased from 11.8 to $3.0 \mathrm{~mm}$ when the cumene hydroperoxide concentration was decreased from 1.0 to $0.3 \mathrm{~mm}$. One explanation of the results in Fig. 5 is that cumene hydroperoxide competes with substrate for binding to the cytochrome while $\mathrm{H}_{2} \mathrm{O}_{2}$ does not.

Source of oxygen atom in product. When the cumene hydroperoxide-dependent hydroxylation of cyclohexane was carried out in a medium enriched in $\mathrm{H}_{2}{ }^{18} \mathrm{O}$, the resulting cyclohexanol, isolated as the trimethylsilyl ether, was found to have derived only $8.6 \%$ of its oxygen from water (Table V). Since, as already shown, peroxide-dependent hydroxylations do not require molecular oxygen, it appears that over $90 \%$ of the oxygen must have been derived from cumene hydroperoxide. The low incorpora-

\footnotetext{
${ }^{5}$ Guengerich, F. P., and Coon, M. J., unpublished results.
}

tion of ${ }^{18} \mathrm{O}$ from water may be due to a slow exchange reaction between water and some other component, such as activated oxygen, but has not been studied further.

Stoichiometry of $N, N$-dimethylaniline demethylation. The data in Table VI show the stoichiometry of the cumene hydroperoxide-dependent reaction with $N, N$-dimethylaniline as the substrate. Control experiments were included with either $P$ $450_{\mathrm{LM}}$ or substrate omitted, and only in the case of cumyl alcohol formation in the absence of substrate was a correction found to be necessary. The results indicate that essentially equimolar amounts of formaldehyde, $N$-methylaniline, and cumyl alcohol are formed in the reaction.

\section{DISCUSSION}

The hydroxylation reactions catalyzed by $P-450_{\mathrm{LM}}$ in the presence of NADPH and NADPH-cytochrome $P-450$ reductase are illustrated by Reaction [1], in which $\mathrm{RH}$ represents the substrate:

$$
\begin{aligned}
\mathrm{RH}+\mathrm{O}_{2} & +\mathrm{NADPH}+\mathrm{H}^{+} \\
& \rightarrow \mathrm{ROH}+\mathrm{H}_{2} \mathrm{O}+\mathrm{NADP}^{+} .
\end{aligned}
$$

The stoichiometry of the reaction has been established in the reconstituted system (40) and in microsomal suspensions (41). As shown in the present paper, the substrate hydroxylation catalyzed by $P-450_{\mathrm{LM}}$
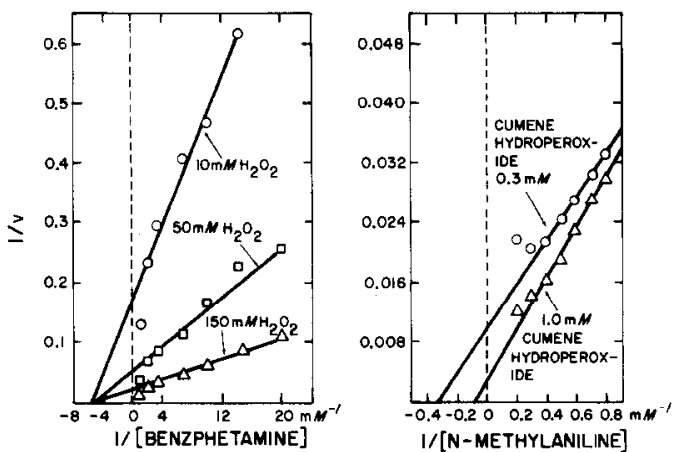

FIG. 5. Effect of hydrogen peroxide concentration on the $K_{m}$ of benzphetamine and of cumene hydroperoxide concentration on the $K_{m}$ of $N$-methylaniline as determined by Lineweaver-Burk plots. The incubation times were 1 and $2 \mathrm{~min}$, respectively. Velocity is expressed as nanomoles of formaldehyde liberated per nanomole of $P-450_{\mathrm{I}, \mathrm{M}}$ per minute. 
TABLE V

Cumene Hydroperoxide-Dependent Hydroxylation of CycloheXaNe IN ${ }^{18} \mathrm{O}$-ENRIChed WATER $^{a}$

\begin{tabular}{|c|c|c|c|c|}
\hline \multirow{2}{*}{$\begin{array}{l}\text { Water in } \\
\text { medium }\end{array}$} & \multicolumn{4}{|c|}{ Cyclohexanol } \\
\hline & $m / e$ & Ratio & $\begin{array}{c}\text { Atom\% } \\
\text { excess } \\
{ }^{18} \mathrm{O}\end{array}$ & $\begin{array}{c}\text { Incor- } \\
\text { pora- } \\
\text { tion }(\%\end{array}$ \\
\hline \multirow[t]{2}{*}{ Normal } & $129: 131$ & 63.00 & 0 & 0 \\
\hline & $157: 159$ & 68.91 & 0 & 0 \\
\hline \multirow[t]{2}{*}{${ }^{18} \mathrm{O}$-enriched } & $129: 131$ & 30.46 & 1.65 & 8.5 \\
\hline & $157: 159$ & 31.22 & 1.70 & 8.8 \\
\hline
\end{tabular}

${ }^{a}$ The components of the reaction mixtures were added at $30^{\circ} \mathrm{C}$ in the order and at the concentrations stated in the experimental procedure section, except that $P-450_{\mathrm{LM}}$ was present at a level of $10 \mu \mathrm{M}$ and the total volume was $2 \mathrm{ml}$. The water in the enriched reaction mixture contained $19.7 \% \mathrm{H}_{2}{ }^{18} \mathrm{O}$. A control experiment was carried out in ordinary water. The hydroxylated product was extracted with dichloromethane and treated with $N, O$-bis(trimethylsilyl) acetamide, and the solution was concentrated and applied to a short alumina column. Cyclohexyl trimethylsilyl ether was eluted with $n$-pentane, and the solution was analyzed by gas chromatography/ mass spectrometry, utilizing a 5 -ft $2.5 \%$ SE-30 column operating at $80^{\circ} \mathrm{C}$. The ratios of $m / e$ 129:131 and m/e 157:159 were calculated by computer from intensities of the cyclohexyl trimethylsilyl ether mass spectral peaks.

in the presence of a hydroperoxide $(\mathrm{XOOH})$ has the following stoichiometry:

$$
\mathrm{RH}+\mathrm{XOOH} \rightarrow \mathrm{ROH}+\mathrm{XOH} \text {. }
$$

When an $N$-methyl compound serves as the substrate, the resulting $N$-hydroxymethyl compound is presumably formed and then breaks down spontaneously to form formaldehyde and the demethylated amine. That the oxygen in the hydroxylated product is derived from the hydroperoxide is established by the lack of incorporation of ${ }^{18} \mathrm{O}$-labeled water. Molecular oxygen as the source of the hydroxyl oxygen is ruled out by the experiments performed anaerobically.

Reactions [1] and [2] are stimulated to a similar extent by phospholipid (7), but only the former reaction requires molecular oxygen and is inhibited by carbon monoxide. Presumably, therefore, the activity of $P .450_{\mathrm{LM}}$ in the peroxide-supported reaction does not involve the ferrous state. Ra- himtula et al. (20) have proposed the occurrence of higher valence states in such reactions, and Rahimtula and O'Brien (22) have suggested that a peroxidase-type mechanism may be in operation. The reconstitution of NADPH- and NADH-peroxidase activities from solubilized components of rat liver microsomes has recently been reported (42).

The present studies with highly purified $P-450_{\mathrm{LM}}$ establish that other microsomal electron carriers are not required in the hydroperoxide-supported reactions. Clearly, therefore, the same catalyst is involved in Reactions [1] and [2], and the question may be considered whether the two types of reactions have common mechanistic features. A two-electron reduction of $\mathrm{O}_{2}$ by NADPH in Reaction [1] would yield $\mathrm{H}_{2} \mathrm{O}_{2}$, which could be utilized by cytochrome $P-450$ in functioning as a peroxidase. The results presented in this paper demonstrate that $\mathrm{H}_{2} \mathrm{O}_{2}$, as well as various other peroxides, supports substrate demethylation catalyzed by the purified $P$ $450_{\mathrm{LM}}$. The failure of $\mathrm{H}_{2} \mathrm{O}_{2}$ to function in this manner in microsomal suspensions, as reported by others (43), may have been due to its destruction by catalase or other contaminating enzymes.

The relatively high concentration of hydrogen peroxide required compared with that needed with the alkyl hydroperoxides suggests that the species actually binding to the enzyme surface may be the hydroperoxide ion, $\mathrm{HO}_{2}{ }^{-}$, which could coordinate more strongly to the iron atom. Calculation based on the known $\mathrm{p} K_{\mathrm{a}}$ of hydrogen peroxide of 11.6 (44) shows that, at the concentration of hydrogen peroxide usually employed (50 $\mathrm{mm}$ ) at $\mathrm{pH} 7.4$, the concentration of $\mathrm{HO}_{2}^{-}$is $3 \mu \mathrm{M}$. Postulation of $\mathrm{HO}_{2}^{-}$as the active species explains the observed shape of the $\mathrm{pH}$ profile for the $\mathrm{H}_{2} \mathrm{O}_{2}$-dependent reactions. As the $\mathrm{pH}$ increases the concentration of $\mathrm{HO}_{2}^{-}$will also increase, resulting in a greater rate. $\mathrm{Hy}$ droperoxides containing an alkyl residue may bind at the substrate-binding site and consequently not require a preliminary ionization step.

We envision a mechanism sharing common features with that of peroxideses (Fig. 6). Binding of substrate and two-elec- 
TABLE VI

Stoichiometry of Peroxide-Supponted Demethylation Reactiona

\begin{tabular}{lccccc}
\hline Component determined & \multicolumn{4}{c}{ Amount of component (nmol) } \\
\cline { 2 - 6 } & $\begin{array}{c}\text { Complete sys- } \\
\text { tem }\end{array}$ & $\begin{array}{c}P_{-450_{\text {LM }} \text { omit- }} \\
\text { ted }\end{array}$ & $\begin{array}{c}\text { Substrate } \\
\text { omitted }\end{array}$ & Net change & $\begin{array}{c}\text { Ratio relative } \\
\text { to } N \text {-methyl- } \\
\text { aniline }\end{array}$ \\
\hline$N$-methylaniline & 518 & 0 & 0 & +518 & 1.0 \\
Formaldehyde & 438 & 0 & 0 & +438 & 0.8 \\
Cumyl alcohol & 684 & 0 & 161 & +523 & 1.0 \\
\hline
\end{tabular}

"Reaction mixtures containing $2.1 \mathrm{nmol}$ of $P-450_{\mathrm{LM}}, 7.0 \mu \mathrm{mol}$ of $N, N$-dimethylaniline, $3.0 \mu \mathrm{mol}$ of cumene hydroperoxide, and the usual buffer and phospholipid, in a final volume of $1.5 \mathrm{ml}$, were incubated for 5 min at $30^{\circ} \mathrm{C}$. Formaldehyde was determined by a modification of the Nash method in which color development was allowed to take place for $35 \mathrm{~min}$ at $25^{\circ} \mathrm{C}$; under these conditions formaldehyde was stable in the presence of the peroxide. For determination of the other products the reaction was stopped by the addition of $0.5 \mathrm{ml}$ of $0.25 \mathrm{M} \mathrm{NaOH}$, and the mixture was extracted with $5.0 \mathrm{ml}$ of chloroform. The chloroform layer was concentrated to $0.5 \mathrm{ml}$ on a rotary evaporator, and aliquots were injected into a gas-liquid chromatograph equipped with a flame ionization detector and a glass column ( $5 \mathrm{ft} \times 1 / 8$ in.) containing $1 \%$ Carbowax $20 \mathrm{M}$ on Diatoport $\mathrm{S}\left(80 / 100\right.$ mesh). The temperature was $100^{\circ} \mathrm{C}$ and the carrier gas was $\mathrm{N}_{2}$. The amounts of cumyl alcohol and $N$-methylaniline were estimated by comparison with standards. The data are averages of at least two determinations.

${ }^{b}$ The cumyl alcohol values are corrected for a small amount of this compound which occurs as a contaminant in the purified cumene hydroperoxide.

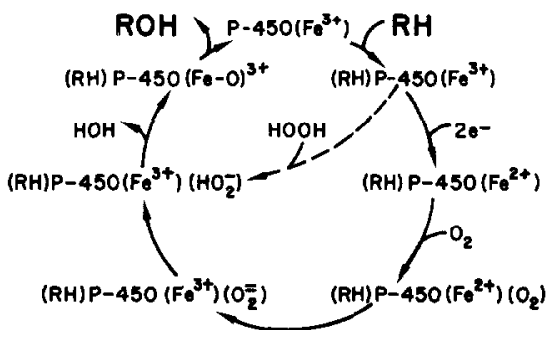

Fig. 6. Proposed mechanism for catalytic action of liver microsomal cytochrome P-450.

tron reduction (with formation of the ferrous protein and with a second electron bound elsewhere in this hemeprotein) (11), followed by binding of oxygen and protonation generates a ternary peroxide complex. This complex may also be produced by direct interaction of substrate-bound ferric $P-450_{\mathrm{LM}}$ with hydrogen peroxide, as indicated. Further protonation and subsequent loss of a molecule of water leaves an activated oxygen species which rapidly inserts an oxygen atom into a favorably positioned $\mathrm{C}-\mathrm{H}$ bond of the substrate. Dissociation of the hydroxylated product regenerates the free ferric form of the enzyme. The protonation state of the various intermediates shown in Fig. 6 is largely speculative.

The activated oxygen moiety appears to be an oxenoid species, which we have formulated as a ferric-bound oxygen atom, although we recognize that other resonance structures involving higher oxidation states of the iron or the porphyrin (45) may contribute. Such an intermediate is analogous to Compound I of catalase and peroxidase. In the case of cytochrome $P$. 450 , the activated oxygen is reduced by reaction with a $\mathrm{C}-\mathrm{H}$ bond, while, in catalase, Compound $\mathrm{I}$ is reduced by abstraction of the hydrogen atoms from a second molecule of hydrogen peroxide. Schonbaum and Lo (46) have provided evidence that Compound I of horseradish peroxidase contains a single oxygen atom. Similarly Hager et al. (47) have shown through ${ }^{18} \mathrm{O}$-labeling studies and stoichiometry determinations that Compound I of chloroperoxidase contains one oxygen atom. In addition, $\mathrm{Ra}$ himtula et al. (48) have demonstrated the migration and retention of a hydrogen atom ("NIH shift") during hydroxylation of $4-\left[{ }^{3} \mathrm{H}\right]$ acetanilide. The percentage of retention was the same in a reconstituted system containing cytochrome $P-448$ in NADPH-dependent and cumene hydroperoxide-dependent reactions. These authors interpreted their results as evidence for the intermediacy of an oxenoid species.

In summary, we propose that cyto- 
chrome $P-450$ functions through a peroxidase-like mechanism in which peroxide is generated at the active site by reduction of bound oxygen. We have shown that the requirement for molecular oxygen, NADPH, and NADPH-cytochrome reductase may be eliminated by substitution of $\mathrm{H}_{2} \mathrm{O}_{2}$, alkyl hydroperoxides, or peracids for these components. The peroxides may be able to generate an activated oxygen which is capable of hydroxylating substrates and may be essentially the same as the intermediate in the reaction cycle of cytochrome $P-450$ in the complete reconstituted system.

\section{ACKNOWLEDGMENTS}

We are grateful to Dr. H. E. Radtke, who participated in preliminary experiments, to Dr. A. Rahimtula and Dr. P. J. O'Brien for helpful discussions, to Sylvia B. Dahl, Christina Beatham, and Barbara M. Michniewicz for research assistance, and to Michael Lutz for the mass spectral measurements.

\section{REFERENCES}

1. Radtke, H. E., ANd Coon, M. J. (1974) Fed. Proc. 33, 588.

2. Nordblom, G. D., White, R. E., and RahimTulA, A. (1975) Fed. Proc. 34, 622.

3. Lu, A. Y. H., ANd Coon, M. J. (1968) J. Biol. Chem. 243, 1331-1332.

4. Coon, M. J., AND Lu, A. Y. H. (1969) in Microsomes and Drug Oxidations (Gillette, J. R., et al., eds), pp. 151-166, Academic Press, New York.

5. Lu, A. Y. H., Junk, K. W., and Coon, M. J. (1969) J. Biol. Chem. 244, 3714-3721.

6. Strobel, H. W., Lu, A. Y. H., Heidema, J., AND Coon, M. J. (1970) J. Biol. Chem. 245, 48514854 .

7. van der Hoeven, T. A., AND Coon, M. J. (1974) J. Biol. Chem, 249, 6302-6310.

8. van der Hoeven, T. A., Haugen, D. A., and Coon, M. J. (1974) Biochem. Biophys. Res. Cummun. 60, 569-575.

9. Haugen, D. A., van der Hoeven, T. A., AND Coon, M. J. (1975) J. Biol. Chem. 250, 35673570.

10. Ballou, D. P., Veeger, C., van der Hoeven, T. A., AND Coon, M. J. (1974) FEBS Lett. 38, 337-340.

11. Guengerich, F. P., Ballou, D. P., and Coon, M. J. (1975) J. Biol. Chem. 250, 7405-7414.

12. Estabrook, R. W., Hildebrandt, A. G., Baron, J., NetTer, K. J., aNd Leibman, K. (1971) Biochem. Biophys. Res. Commun. 42, 132-139.
13. Gunsalus, I. C., Tyson, C. A., Tsai, R., and I.тsсомв, J. П. (1971) Chem. Biol. Interact. 4, $75-78$.

14. Ishimura, Y., Ullrich, V., and Peterson, J. A. (1971) Biochem. Biophys. Res. Commun. 42, 140-146.

15. Strobel, H. W., ANd Coon, M. J. (1971) J. Biol. Chem. 246, 7826-7829.

16. Chen, C., and Lin, C. C. (1968) Biochim. Biophys. Acta 170, 366-374.

17. Chen, C., and LrN, C. C. (1969) Biochim. Biophys. Acta 184, 634-640.

18. Van Lier, J. E., ANd Smith, L. L. (1970) Biochem. Biophys. Res. Commun. 10, 510-516.

19. Kadlubar, F. F., Morton, K. C., and Ziegler, D. M. (1973) Biochem. Biophys. Res. Commun. 54, 1255-1261.

20. Rahimtula, A. D., ANd O'Brien, P. J. (1974) Biochem. Biophys. Res. Commun. 60, 440-447.

21. Ellin, $\AA$., ANd Orrenius, S. (1975) FEBS Lett. 50, 378-381.

22. Rahimtula, A. D., and O'Brien, P. J. (1975) Biochem. Biophys. Res. Commun. 62, 268-275.

23. Hrycay, E. G., Gustafsson, J. A., IngelmanSundberg, M., and Ernster, L. (1975) FEBS Lett. 56, 161-165.

24. Hrycay, E. G., Gustafsson, J. A., IngelmanSundberg, M., ANd Ernster, L. (1975) Biochem. Biophys. Res. Commun. 66, 209-216.

25. НосH, H., and LaNG, S. (1944) Chem. Ber. 77, 257-264.

26. Schuster, R. E., Scott, J. E., and Casanova, J., JR. (1974) Org. Syn. Coll. Vol. 5, 772-774.

27. ZIEgleR, K., AND SChNeld, B. (1924) Justus Liebig's Ann. Chem. 437, 227-255.

28. Brown, H. C., Brady, J. D., Grayson, M., and Bonner, W. H. (1957) J. Amer. Chem. Soc. 79, 1897-1903.

29. Williams, H. R., aNd Mosher, H. S. (1954) $J$. Amer. Chem. Soc. 76, 2984-2987.

30. Martin, A. J. (1960) in Organic Analysis (Mitchell, J., Jr., Kolthoff, I. M., Proskauer, E. S., and Weissberger, A., eds.), Vol. 4, pp. 15-16, Interscience, New York.

31. Poland, A. P., ANd Nebert, D. W., (1973) $J$. Pharmacol. Exp. Ther. 184, 269-277.

32. Gholson, R. K., Baptist, J. N., ANd Coon, M. J. (1963) Biochemistry 2, 1155-1159.

33. NASH, T. (1953) Biochem. J. 55, 416-421.

34. Cochin, J., ANd Axelrod, J. (1959) J. Pharmacol. Exp. Ther. 125, 105-110.

35. Lu, A. Y. H., Strobel, H. W., and Coon, M. J. (1969) Biochem. Biophys. Res. Commun. 36, $545-551$.

36. Omura, T., and Sato, R. (1964) J.Biol. Chem. 239, 2370-2378.

37. Nishibayashi, H., Omura, T., and Sato, $R$. (1966) Biochim. Biophys. Acta 118, 651-654. 
38. Schenkman, J. B., Remmer, H., and EstaBROOK, R. W. (1967) Mol. Pharmacol. 3, 113123.

39. Gillette, J. R., Dingell, J. V., and Brodie, B. B. (1958) Nature (London) 181, 898-899.

40. Lu, A. Y. H., Strobel, H. W., and Coon, M. J. (1970) Mol. Pharmacol. 6, 213-220.

41. Sasame, H. A., Mitchell, J. R., Thorgeirsson, S., and Gillette, J. R. (1973) Drug Metab. Disp. 1, 150-155.

42. HRYCay, E. G., Jonen, H. G., LU, A. Y. H., AND Levin, W. (1975) Arch. Biochem. Biophys. 166, 145-151.

43. Rahimtula, A. D., O'Brien, P. J., Hrycay, E. G., Peterson, J. A., and Estabrook, R. W.
(1974) Biochem. Biophys. Res. Commun. 60, 695-702.

44. Davies, A. G. (1961) Organic Peroxides, p. 34, Butterworths, London.

45. Dolphin, D., Forman, A., Borg, D. C., Fajer, J., ANd Felton, R. H. (1971) Proc. Nat. Acad. Sci. USA 68, 614-618.

46. Schonbaum, G. R., and Lo, S. (1972) J. Biol. Chem. 247, 3353-3360.

47. Hager, L. P., Doubek, D. L., Silverstein, R. M., Hargis, J. H., and Martin, J. C. (1972) J. Amer. Chem. Soc. 94, 4364-4366.

48. Rahimtula, A. D., O'Brien, P. J., Seifried, H. E., and Jerina, D. M. (1975) Fed. Proc. 34, 623. 